\title{
KONSEP PENDIDIKAN ANAK MENURUT IBNU KHALDŪN DALAM KITĀB MUQODDIMAH
}

\author{
Noor Hidayah \\ MTs NU Hasyim Ay`ari 02 Kudus, Jawa Tengah, Indonesia. \\ noor.hidayahku@yahoo.com
}

\begin{abstract}
Abstrak
Kajian ini mengeksplorasi tentang konsep dan pemikiran Ibnu Khaldūn tentang pendidikan anak yang menyoroti mengenai peran, tugas dan tanggung jawab pendidik terhadap anak dalam proses belajar mengajar atau interaksi edukatif. Pendekatan dalam penelitian ini adalah penelitian kepustakaan. Konsep pendidikan anak menurut Ibnu Khaldūn dalam kitab Muqaddimah didasarkan pada Alquran, kemudian dilandasi dengan ketentuan intelektual dan akal. Tujuan pendidikan anak menurut pemikiran Ibnu Khaldūn dalam kitāb Muqaddimah adalah membentuk anak supaya memiliki akhlak yang mulia, kepribadian yang baik dan tangguh, memiliki malakah atau ketrampilan dan menguasai ilmu-ilmu agama (naqliyah) dan ilmu-ilmu umum (aqliyah) untuk eksistensi kelangsugan hidup mereka. Hasil dari kajian ini menunjukkan bahwa konsep pendidikan anak menurut Ibnu Khaldūn dalam kitāab Muqaddimah nya ternyata relevan dengan tokoh-tokoh pendidikan Barat, misalnya Locke, J.J. Rousseau Locke, Fouerster, dan John Dewey, meskipun dasar pijakan dalam berpikir mereka berbeda dengan Ibnu Khaldūn, dimana mereka lebih menekankan dan didominasi oleh pijakan akal dan rasional.
\end{abstract}

Kata kunci: pendidikan, Ibnu Khaldūn, kitāb Muqaddimah 
Noor Hidayah

\begin{abstract}
THE CONCEPT OF THE CHILDREN EDUCATION ACCORDING TO IBN KHALDŪN (STUDY ON THE BOOK OF THE MUQADDIMMAH). This study explores the concept and thought of Ibn Khaldun about the children education that highlights about the role, duties and responsibilities of educators in the process of teaching and learning or educational interaction. This study uses library research. The concept of the children education according to Ibn Khaldun in the book of Muqaddimmah are based on the Qur'an, and then be based on the intellectual provisions and sense. The purpose of the children education according to Ibn Khaldun's thought in the book of Muqaddimmah is forming the children to have noble morals, good and tough personality, skills and master the religious studies (naqliyah) and general studies (aqliyah) for their lives existence. The result of this study show that the concept of the children education according to Ibn Khaldun in the book of Muqaddimmah is still relevant to Western education figures, such as Locke, Rousseau, Locke, J.J. Fouerster, and John Dewey, but their basic in thinking are different with Ibn Khaldun, they are more stressed and dominated by reason and rational basic.
\end{abstract}

Keywords: children education, Ibn Khaldūn, Muqaddimmah book

\title{
A. Pendahuluan
}

Pendidikan merupakan salah satu penopang sebuah negara, ia memiliki peranan penting dalam upaya pencapaian kemajuan bangsa. Pendidikan merupakan salah satu fenomena sosial yang sangat mempengaruhi pertumbuhan dan perkembangan individu dan masyarakat yang melibatkan orang tua, pendidikan dan lingkungan. Anak merupakan bagian dari masyarakat sebagai individu yang pada prinsipnya memiliki akal yang sehat yang dapat dan harus dimanfaatkan untuk mencari ilmu pengetahuan. Potensi tersebut memberi kemungkinan kepada anak untuk mengembangkan kepribadiannya. Pengembangan akal pikiran yang sehat dilatarbelakangi oleh kesadaran berfikir yang dimiliki oleh anak (Ulwan, 1990: vii).

Dalam perkembangan kepribadian, akal fikiran dan potensi anak yang melalui fase-fase perkembangan tertentu, anak memerlukan bimbingan, pengajaran, pengendalian dan kontrol 
dari orang tua dan pendidik. Anak yang merupakan dasar awal dari pembentukan menjadi dewasa harus diperhatikan dengan sungguh perkembangannya oleh orang tua dan pendidik. Hal ini dengan tujuan mempersiapkan perkembangan anak agar mampu berperan serta secara berkesinambungan dalam pembangunan manusia yang berkembang terus dan mampu beramal kebajikan dalam arti berakhlak mulia selama dalam upaya mencari kebahagiaan di dunia dan akhiratnya (Al-Jumbulati, 1994: 4). Anak tidak dapat tumbuh dan berkembang serta menerima ilmu pengetahuan begitu saja, tetapi harus dengan pengajaran dan bimbingan dari orang tua dan pendidik. Orang tua dan pendidiklah dan didukung oleh lingkungan baik yang berperan dalam mengembangkan bakat dan minat anak, karena factor yang dari dalam yaitu faktor keturunan tidak banyak pengaruhnya pada diri anak. Hal ini dapat dikatakan bahwa anak secara fitri (alami) bersih dari warna tertentu dan mirip dengan teori tabularasa atau lembaran putih yang dikemukakan oleh tokoh pendidikan Barat yaitu John Locke. Sedangkan proses belajar serta mendapatkan ilmu pengetahuan sama dengan proses menulis dan membuat garis di atas lembaran putih tersebut (Sulaiman, 1991: 92).

Teori John Locke dan juga J.J. Rousseau tentang anak-anak yang baru lahir dalam keadaan bersih bagaikan kertas putih. Aliran ini punya pengikut yang besar di Amerika Serikat serta membuka jalan bagi tumbuhnya aliran-aliran yang besar pengaruhnya dalam dunia psikologi yanitu Behaviorisme yang terus berkembang sampai sekarang. Ibnu Khaldūn terlahir 27 Mei $1331 \mathrm{M}$ dari keluarga politisi, intelektual dan aristocrat di Moorsih, telah lama mengedepankan ide tersebut meskipun dalam versi yang berbeda. Konsep tersebut sejalan dengan hadits Nabi Muhammad Saw. Yaitu: "tidak ada bayi yang dilahirkan kecuali dalam keadaan suci (fitrah), kedua orang tuanyalah yang menjadikannya Yahudi, Nasrani atau Majusi" (Muslim, tt: 458). Di sini dapat ditarik pengertian bahwa peranan dan tanggung jawab orang tua selaku pendidik utama dan pertama dan pendidik dalam arti guru sangat besar dalam mengantarkan anak ke jenjang pendidikan yang lebih baik. Orang tua juga berperan membentuk anak agar tumbuh dan berkembang dengan baik dan sempurna hingga dewasa. 
Perkembangan dunia pendidikan tentunya tidak akan terlepas dari sumbangsih para ilmuwan yang mencurahkan segala perhatiannya pada dunia pendidikan ini. Begitu pun yang dilakukan oleh para ulama sebagai yang merasa berkewajiban untuk menyebarluaskan ilmu. Salah satu ulama besar, filosof, psikolog dan sosiolog sekaligus intelektual muslim yakni Ibnu Khaldūn. Maka dari sinilah dirasa perlu menampilkan konsep dan pemikiran beliau tentang pendidikan anak yang menyoroti mengenai peran, tugas dan tanggung jawab pendidik terhadap anak dalam proses belajar mengajar atau interaksi edukatif. Beliau mengatakan: "tidak cukup seorang pendidik hanya membekali anak dengan ilmu pengetahuan saja agar mereka menjadi orang yang berilmu pengetahuan menambah kemampuannya dalam belajar Akan tetapi juga pendidik wajib memperbaiki metoda dalam penyajian ilmu kepada anak didiknya; dan hal itu tidak akan sempurna kecuali dengan lebih dahulu mempelajari hidup kwajiban anak dan mengetahui tingkat-tingkat kematangannya serta bakat-bakat ilmiahnya, sehingga ia mampu menerapkan sesuai dengan tingkat pikiran mereka" (Al-Jumbulati, 1994: 195-196).

Sosok figur Ibnu Khaldūn sebagai sarjana dan ulama besar, kebanggaan umat Islam dan pencipta ilmu sosial benar-benar merupakan pujaan dan bintang kejora (Thoha, 1979: 58). Ibnu Khaldūn sebagai ulama dan sarjana besar menurut etimologi dan semantiknya, keahliannya dan ilmunya tidak tanggung-tanggung di seluruh bidang ilmu-ilmu naqliyah yang mencakup ilmu-ilmu agama dan ilmu alat dan ilmu-ilmu aqliyah yang meliputi ilmu-ilmu umum. Ibnu Khaldun tidak hanya seorang sosiolog, beliau juga seorang sejarawan dan tokoh pemikir pendidikan, hal ini ditinjau pada pendidikan anak-anak. Pengalamannya sebagai mahaguru di Universitas al-Azhar yang dibangun oleh khalifah al-Muiz dari dinasti Fatimiyah yang ada di Kairo Mesir dan guru besar di universitas Sragtmus. Selama 20 tahun lebih beliau memberikan kuliah dan tentunya beliau mempunyai wawasan yang luas, pemikiran yang mendalam sehingga patut dikaji dan diteliti.

Konsep dan pemikiran Ibnu Kaldun khususnya tentang pendidikan anak masih aktual dan pantas untuk digali serta ditampilkan, seperti orientasi pendekatan ilmu kepada anak-anak melalui contoh kehidupan, pendidik harus membawakan teladan 
utama contoh yang baik bagi anak dan sebagainya. Konsep dan pemikiran Ibnu Khaldūn tidak dapat dipisahkan dari akar pemikiran Islamnya. Disinilah letak alasan Iqbal mengatakan bahwa seluruh semangat Muqaddimah yang merupakan manifestasi pemikiran Ibnu Khaldūn, diilhami pengarangnya dari al-Qur'an sebagai sumber utama dan pertama dari ajaran Islam. Dengan demikian konsep Ibnu Khaldūn dapat dibaca melalui setting sosial yang mengitarinya yang diungkapkan baik secara lisan maupun tulisan sebagai sebuah kecenderungan.

Dari uraian di atas, kajian ini dilakukan karena adanya suatu masalah yang membutuhkan pembahasan atau penyelesaian. Masalah dalam penelitian berarti juga fokus yang menjadi pusat pembahasan. Secara umum masalah adalah suatu keadaan yang bersumber dari dua faktor atau lebih yang menghasilkan situasi yang membingungkan (Moleong, 1993: 62). Dalam penelitian ini masalah ini terfokus pada bagaimana konsep pendidikan anak menurut Ibnu Khaldūn dalam kitab Muqaddimah dan relevansinya terhadap pendidikan anak pada masa sekarang ini.

\section{B. Pembahasan}

\section{Biografi Ibnu Khaldūn}

\section{a. Nama dan Asal Kelahirannya}

Nama lengkap Ibnu Khaldūn yaitu Abdu al-Rahman Ibn Muhammad Ibn Muhammad Ibn Muhammad Ibn al-hasan bin Jabiribn Muhammad Ibn Ibrahim Ibn Khalid Ibn Utsman Ibn Hani Ibn Khattab Ibn Kuraib ibn Ma'dikarib Ibn al-Harits Ibn Wail Ibn Hujar atau lebih dikenal dengan sebutan Abdur Rahman Abu Zayd Muhammad Ibn Khaldūn. Abu Zaid Abdul Rahman Ibnu Khaldūn dilahirkan di Tunisia pada tanggal 1 Ramadhan $734 \mathrm{H}$, bertepatan dengan tanggal 27 Mei 1332 M. Keluarganya berasal dari Hadramaut, sebuah daerah pertanian yang cukup subur di kawasan Jazirah Arab sebelah selatan. Mereka datang di Spanyol pada masa pemulaan pendudukan Islam di sana (B. Lewis, et.Al, 1971: 825). Nenek moyangnya berasal dari Hadramaut yang kemudian berimigrasi ke Sevilla pada abad ke VIII setelah semenanjung itu dikuasai Arab Muslim (Ma'arif, 1996: 11). 
Nenek moyang Ibnu Khaldūn berasal dari salah satu suku yang ada di daerah Arab sebelah selatan tepatnya di wilayah Yaman. Ibnu Khaldūn adalah cucu keempat dari keturunan Khaldūn, yang juga menjadi nama sukunya, nama aslinya Khaldūn adalah Khalid, beliau dikenal dengan nama Khaldūn karena sesuai dengan kebiasaan orang-orang Andalusia dan orang-orang Maghribi yang menambahkan huruf wawu dan nun di belakang nama-nama orang terkemuka sebagai tanda penghormatan dan pengagungan, seperti Hamid menjadi Hamdun, Zaid menjadi Zaidun dan Khalid menjadi Khaldūn (Wafi, 1985: 4).

Perebutan kembali Spanyol oleh umat Kristen memaksa umat Islam melintasi selat Jiblaltar menuju ke Afrika pada tahun 1248 M. Tidak begitu lama kemudian Sevilla dirampas kembali oleh Ferdinand III dari Leon dan Gastilla. Keluatga Ibnu Khaldūn mengambil keputusan yang bijaksana, mereka menyadari akan akibat buruk yang mungkin terjadi menimpa mereka. Untuk sementara waktu mereka pindah ke Centau dimana pada waktu itu gubernurnya adalah orang dari Hafs. Gubernur tersebut menerima mereka dengan tangan terbuka. Kepala keluarga mereka pada waktu itu adalah al-Hasan Ibn Muhammad Ibn Khaldūn, kakek keempat dari pengarang kitab Muqaddimah. Selanjutnya tidak berapa lama di Centa, al-Hasan pergi Ke Mekah untuk menunaikan ibadah haji. Setelah kembali dari Mekah ia menetap di Bougie sebagai pegawai tinggi dari Kerajaan Hafsah.

Tempat tinggal mereka sebagian besar di Tunisia. Pada waktu amirnya bernama Abu Zakaria. Dari beliaulah al-Hasan memperoleh bantuan dan perlindungan. Setelah Abu Zakaria meninggal dunia kemudian digantikan anaknya yang bernama Yahya, kemudian saudaranya yang bernama Abu Ishak, selama itu pula Bani Khaldūn dapat menikmati kekuasaan dan kekayaan.

\section{b. Pendidikan dan Pengalamannya}

1) Pendidikan Ibnu Khaldūn

Pendidikan Ibnu Khaldūn sewaktu kanak-kanak dan remaja tidak berbeda dengan anak-anak lainnya yaitu belajar mengaji, belajar ilmu-ilmu yang berkaitan dengan pemahaman dan penafsiran al-Qur'an. Beliau belajar dalam bidang tersebut kepada Muhammad 
Ibn Sa'id Burnail. Selain belajar bahasa Arab kepada ayahnya sendiri, beliau juga menimba ilmu bahasa Arab kepada Syaikh Muhammad Ibn al-Arabi al-Hushairi, Syaikh Muhammad al-Syawwasy al-Zarzali, Syaikh Ahmad Ibn al-Qoshor dan Syaikh Muhammad Ibn Bahr. Ilmu hadits dan ilmu hukum Islam diperoleh dari seorang yang cerdik dan masyhur yaitu Syaikh Syamsuddin Muhammad Ibn Jabir Ibn Sultan al-Wadiasyi (1274-1348 M), Syaikh Muhammad al-Qadir dan Muhammad Ibn Abd as-Salam al-Hawwari (Thoha, 1979: 76).

Sebagaimana biasanya, sikap anak-anak remaja yang berusia antara 7-13 tahun dimana beliau begitu saja menerima segala apa yang diajarkan kepadanya. Hal itu juga terjadi pada diri Ibnu Khaldūn. Namun demikian ketika berusia antara 15 tahun dalam diri Ibnu Khaldūn terlihat adanya suatu perubahan pada sikap dan tindak lakunya, seperti diketahui pada masa tersebut merupakan masa yang paling menentukan bagi perkembangan intelektual seorang manusia muda.

2) Pengalaman Ibnu Khaldūn

Daerah kekuasaan Afrika Utara saat itu dapat diibaratkan seperti sebuah pentas politik dimana setiap orang dapat menyaksikan pergolakan-pergolakan politik yang sangat hebat, saling berebut kekuasaan diantara para warga masyarakat. Hal itu disebabkan runtuhnhya kerajaan al-Muwahhidun dan munculnya negara-negara kecil serta keamiran-keamiran kecil yang terdiri dari kesultanan Bani Hafs di Tunis, Kesultanan Bani Abdul Wad di Tiemen, dan Kesultanan Bani Marin di Fez dan Marokko (Wafi, 1985: 167). Ketiga kesultanan itu tetap di dalam pertikaian sesama mereka, sampai kemudian para amir dari kesultanan Bani Hafs dan kesultanan Bani Abdul Wad mampu mengendalikan situasi dan kondisi tersebut serta menempati wilayah masing-masing.

Pada mulanya Ibnu Khaldūn bertugas di kesultanan Bani Hafs sebagai karyawan tata usaha untuk menulis surat yang dikeluarkan oleh Sultan. Kemudian di kesultanan Bani Marin, Ibnu Khaldūn diangkat oleh Sultan Bani Inan sebagai sekretaris Negara dan juga sebagai anggota majlis ilmu pengetahuan (Raliby, 1965: 20). Ibnu Khaldūn belum puas dengan jabatan yang diembannya. Beliau ikut mendukung usaha kudeta dalam arti pemberontakan terhadap 
sultan yang dilakukan oleh Amir Abu Adullah Muhammad, dan raja Bougie yang baru saja dirampas ternyata dijadikan tahanan di Fez. Akhirnya Ibnu Khaldūn dimasukkan ke dalam penjara, tepatnya pada tahun $758 \mathrm{H}$. Tak lama kemudian Ibnu Khaldūn dibebaskan dari penjara oleh Sultan Abu Inan. Pada tahun 759 H/1358 M, setelah mempersembahkan kepada Sultan 700 syair yang berisi memuji kehebatan Sultan (Thoha, 1979: 78).

Selanjutnya pada pertengahan tahun $766 \mathrm{H}$, beliau meninggalkan Granada untuk kembali ke Bijayah. Dengan senang hati Sultan Bijayah menhyambut kedatangannya dan tidak lama kemudian Ibnu Khaldūn diangkat menjadi Perdana Menteri sebagaimana dijanjikan sewaktu sama-sama dipenjara.

Dengan demikian Ibnu Khaldūn telah menggapai impiannya untuk memegang pangkat dan kedudukan tertinggi pada pemerintahan. Disamping itu beliau juga memberikan kuliah di Masjid Raya, tugas yang pernah terlupakan kapanpun dan dimamanpub selama hidupnya. Selama kurang lebih empat tahun berpetualangan serta memperoleh setumpuk pengalamanpengalaman politik, Ibnu Khaldūn merasa jenuh terhadap terhadap persoalan politik, sebagai wujudnya beliau memutuskan untuk menetap di Qol'at Ibn Salamah, yaitu sebuah puri di desa dalam propinsi Iran. Disanalah beliau menghirup udara kehidupan yang segar dan tenang. Hari-harinya dipergunakan untuk studi menelaah dan mengarang kitab. Ketika usia 45 tahun penyelidikan dan studinya sudah cukup matang. Selama seperempat abad beliau berkecimpung di dalam dunia politik, pindah dari kesultanan atau beralih ke kesultanan yang lainnya dengan jabatan yang tergolong cukup tinggi. Hijrah dfari Maghribi ke Andalusia, kota dan kabilah telah dilalui serta dikarunginya (Raliby, 1965: 30). Kegiatan merenung, kontemplasi dan berpikir, menulis serta mengarang beliau aktifkan, sehingga dapat membuahkan hasil yang berupa ilmiah tentang sejarah umat manusia yang dinamakannya kitab al-'bar wa Diwan al-Mubatada wa al-Khabar fi Ayyam al-Araby wal Ajami wal Bar Bar wa Manasrahum min Dzawi alp-Sulthan al-Akbar (kitab tentang Ibarat-ibarat dan catatan sejarah terdahulu dan kemudian. Memperbincangkan peristiwa-peristiwa poilitik dari bangsa-bangsa Arab, Asing dan BarBar dan raja-raja besar yang hidup di masa mereka) disingkat dengan 
kitab al-'Ibar saja, sebagai pendahuluan dari kitab sejarah itu maka dikarangnya kitab Muqaddimah.

Muqaddimah itu selesai dikarang oleh beliau pada pertengahan tahun $1377 \mathrm{M}$ dalam jangka waktu lima bulan. Ibnu Khaldūn merasa sangat sukses dengan hasil ciptaannya itu (Raliby: 30). Kemudian Ibnu Khaldūn berkata: "Saya telah menyelesaikan kitab Muqaddimah itu dengan cara yang aneh, saya seperti diilhami, sehingga kata-kata dan pikiran-pikiran seperti mengalir saja ke otakku. Begitu Ibnu Khaldun sampai ke Kairo para ulama dan pendidik khususnya dengan antusias menyambut kehadiran beliau. Mereka mengharapkan adanya tambahan ilmu dari penulis kitab terkenal itu. Tanpa diundang banyak budayawan berkumpul mengelilinginyauntuk mendengarkan ceramahnya serta menyerap dan mencerna ilmu-ilmu khususnya yang berkenaan dengan pembahasan metode dan pemikiran dan konsep yang dituangkan di dalam kitabnya Muqaddimah, oleh karena itu beliau mengambil tempa di aula al-Azhar sebagai tempat kuliahnya (Raliby, 1965: 79).

\section{c. Karya-Karya Ibn Khaldūn}

Sebagaimana telah dikemukakan bahwa salah satu kelebihan Ibnu Khaldūn disamping menguasai berbagai disiplin ilmu, juga telah berhasil menuangkan ide dan gagasannya dalam berbagai bidang ilmu yang dikuasainya dalam bentuk tulisan-tulisan. Beliau termasyhur sebagai ilmuan besar adalah karena buah karya beliau Muqaddimah sebuah kitab pengantar kitab Al-Ibar. Karya monumentalnya tersbut telah membikin para sarjana baik Timur maupun Barat begitu mengaguminya. Karya-karya tersebut merupakan perpaduan kegeniusannya dengan kekayaan pengalamanny, kematangan pribadi, kekuatan hirrahnya, ketajaman menganalisa dan ketangkasan dalam memecahkan masalah sehingga mampu menemukan terobosan baru (Wafi, 1985: 71).Adapun karya-karya Ibnu Khaldūn itu adalah:

\section{Muqaddimah}

Muqaddimah ini merupakan kitab pertama dari kitab al-'Ibar yang terdiri dari bagian muqaddimah (pengantar) dari kitab satu. Kitab Muqaddimah oleh orang Barat disebut dengan prolegomena. Kitab pengantar yang panjang inilah yang merupakan inti seluruh persoalan serta kitab tersebutlah yang mengangkat nama Ibnu 
Khaldūn begitu harum. Adapun isi kitab Muqaddimah tersebut adalah Ibnu Khaldūn mengawali ulasannya secara detail tentang nilai-nilai sejarah dan bentuk-bentuknya, kesalahan-kesalahan yang dilakukan oleh para ahli sejarah di dalam mencatat tanggal dan peristiwa, baik karena disengaja dengan maksud-maksud tertentu atau karena semata-mata karena kecorobohan yang tak disadari. Uraian ini disertai dengan contoh-contoh dan penjelasan yang menarik. Ibnu Khaldūn juga menekankan pentingnya mengetahui fakta-fakta dan peristiwa-peristiwa yang sesuai dengan hukumhukum ilmu sosiologinya.

\section{2. al-'Ibär wa Diwān al-Mubtada' wa al-Khabar fi Ayyām al-Arab wa al-Ajam wa al Babar wa Man Asrohum min Dzawi al-Sultān al- $A k b \bar{a} r$}

Kitab ini kemudian terkenal dengan sebutan al-'Ibar. Kitab ini terdiri dari tiga kitab. Kitab pertama adalah Muqaddimah, sebagai pengantar atau jilid satu dan berisi tentang masyarakat dab cirricirinya yang hakiki pemerintahan, mata pencaharian, penghidupan, keahlian, kealaman dan ilmu pengetahuan dengan segala sebab dan alasannya. KItab kedua meliputi jilid kedua, ketiga, keempat dan kelima. Kitab ini mengulas tentang sejarah bangsa Arab, generasigenerasi mereka dan dinasti-dinasti dari terciptanya alam sampai sekarang. Kitab ini juga menceritakan sekilas tentang bangsa-bangsa yang terkenal seperti Ponteam, Syiria, Persia, Yahudi, Yunani, Romawi, Turki dan Eropa. Kitab ketiga terdiri dari jilid keenam dan ketujuh yang menerangkan sejarah bangsa Barbar dan Zanathayang merupakan bagian dari mereka khususnya kerajaan dan Negara Maghribi (Ahmad, 1979: 254). Dan dipungkasi dengan auto biografi pengarangnya.

\section{3. al-Ta'rif Ibnu Khaldūn wa Rihlatuhu Ghorban wa Syirqon}

Kitab ini oleh orang Barat disebut Autobiografi, dan kemudian disingkat al-Ta'rif (Enam, 1979: 134). Al-Ta'rif merupakan bagian akhir dari kitab al-'Ibar yang dalam beberapa hal mengulas tentang kehidupan Ibnu Khaldūn. Beliau menulis autobigrafinya secara sistematik dengan menggunakan metode ilmiah, terpisah dalam beberapa hal tetapi saling terkait antara satu dengan yang lainnya. Dari sinilah banyak buah karya Ibnu Khaldūn ini hanya sebagian 
yang sampai kepada kita, sehingga terkesan adanya kegterputusan antara generasi muslim masa lampau dengan masa sekarang.

\section{Dasar dan Tujuan Pendidikan Anak Menurut Ibnu Khaldūn}

Menurut Ibnu Khaldūn bahwa ilmu pendidikan bukanlah suatu aktifitas yang semata-mata bersifat pemikiran dan perenungan, serta jauh dari aspek-aspek pragmatis di dalam kehidupan, tetapi ilmu pengetahuan (pendidikan) tidak lain adalah dua buah fenomena sosial, termasuk fenomena sosial yang menjadi ciri masyarakat manusia (Sulaiman, 1991:33). Kehidupan dan semua aktifitas yang merupakan fenomena sosial dari masyarakat haruslah mempunyai dasar. Dasar pendidikan anak menurut Ibnu Khaldūn tidak lepas dari dasar pendidikan Islam. Pendidikan Islam itu didasarkan pada kaedah hukum dalam Alquran dan Hadis.

Athiyah al-Abrasyi menandaskan bahwa dasar pendidikan Islam adalah Alquran dan Hadis, yaitu bahwa pendidikan Islam dibangun atau didasarkan atas kaidah hukum yang ditulis dalam Alquran dan atas sabda Rasulullah (Al-Abrasyi, tt: 284). Dasar pendidikan anak menurut Ibnu Khaldūn adalah Alquran yakni dalam menemukan gagasan-gagasan di bidang pendidikan anak, karena Alquran memberikan pandangan yang mengacu pada kehidupan di dunia dan asas-asas dasarnya memberi petunjuk kepada pendidikan Islam (Abdullah, 1994: 20). Dalam meneliti fenomena yang ada di dalam masyarakat Ibnu Khaldūn menggunakan metode ilmiah yaitu dengan cara observasi dan berpikir secara logika, sehingga dengan penelitiannya memunculkan penemuan tentang teori hubungan sebab akibat atau disebut sunnatullah dan menciptakan teori-teori dan konsep-konsep baru dalam pendidikan anak.

Al-Qur'an sebagai rujukan dan acuan pendidikan anak maka muncullah gagasan baru dalam pendidikan anak yang sesuai dengan kondisi dan situasi yang ada di dalam masyarakat. Gagasan tersebut diperoleh melalui pengamatan dan kajian secara empiris yang dilakukan oleh Ibnu Khaldūn di negara-negara Islam yang ada di Afrika dan Andalusia. Ibnu Khaldūn sendiri menyebutkannya dalam kitab Muqaddi-mahnya:

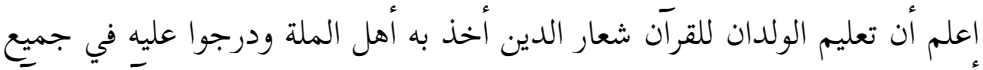

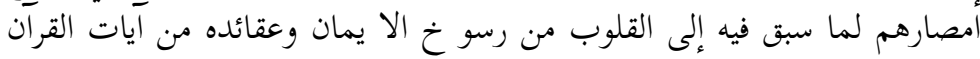


Noor Hidayah

$$
\text { وبعض متون الحديث وصار القرآن أصل التعليم الذي ينبنى عليه ما يحصل بعد }
$$

"Bahwa sesungguhnya mengajar Alquran kepada anak-anak itu merupakan syiar agama atau symbol agama. Ahli agama mengambil dan memasukannya dalam semua masa-masa mereka. Hal itu akan mengilhami hati dengan menancap dan masuknya iman dan akidahnya dari ayat-ayat Alquran dan sebagian dari matan hadits dan Alquran menjadi dasar pengajaran dan fondasi semua keahlian yang diperoleh kemudian (Abdullah, 1994: 20).

Meskipun dalam pernyataan Ibnu Khaldūn tidak disebutkan secara jelas, namun sudah tersirat di dalamnya bahwa Alquran menjadi dasar dari ta'lim (pengajaran). Karena Alquran dan Hadis merupakan dasar agama, maka Ibnu Khaldūn juga mengisyaraktkan kembali pada pentingnya penghafalan pada Alquran. Ibnu Khaldūn mengatakan dalam Muqaddimahnya:

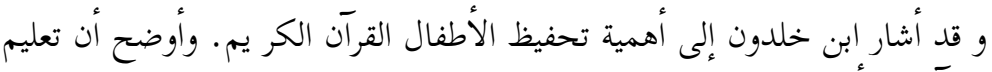

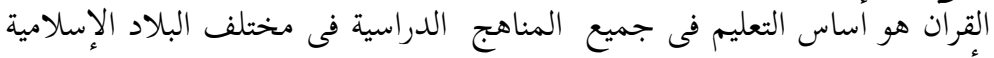

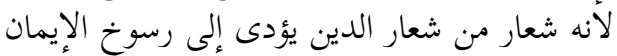

"Ibnu Khaldūn mengisyaratkan pada pentingnya penghafalan Alquran bagi anak-anak, beliau menjelaskan bahwa pengajaran Alquran dalam semua system pengajaran pada berbagai negara-negara Islam, karena Alquran merupakan syiar agama yang dapat mendatangkan pada kuatnya iman" (Al-Abrasyi, tt: 165).

Dari pendapat dan pernyataan Ibnu Khaldūn di atas dapat ditarik kesimpulan bahwasanya Alquran merupakan dasar pendidikan yang juga merupakan dasar pendidikan anak. Adapun tujuan pendidikan anak menurut konsep Ibnu Khaldūn juga tidak disebutkan secara langsung, tetapi dapat diungkapkan bahwa sesungguhnya tujuan pendidikan yang bersumberkan Alquran adalah untuk mencapai tujuan pembentukan akidah atau keimanan yang mendalam pada diri anak dan menumbuhkan dasar-dasar mulia jalan agama yang diturunkan untuk mendidik jiwa manusia serta menegakkan moral dan akhlak yang membangkitkan pada perbuatan baik dan itu merupakan tujuan yang paling pokok dan terpenting dalam pendidikan anak (Al-Jumbulati, 1994: 58).

Hal yang demikian dikatakan Ibnu Khaldūn dengan tegas dalam kitabnya Muqaddimah: 


$$
\begin{aligned}
& \text { إن الغاية فى ذلك الوصول بالوليد إلى رسوخ العقائدالإيمانية فى نفسه، وغرس الذإس }
\end{aligned}
$$

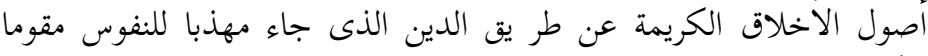

$$
\begin{aligned}
& \text { للأخلاق باعثا للخير الاخلاق الخرية }
\end{aligned}
$$

"Bahwa sesungguhnya tujuan dari hal itu adalah menanmkan anak dan memasukkan akidah keimanan dalam dirinya, dan menanamkan dasar-dasar akhlak yang mulia dari jalan agama yang membersihkan pada jiwa, yang menegakkan akhlak dan membangkitkan kebaikan" (Al-Abrasyi, tt: 258).

Pernyataan di atas didukung oleh sebagian tokoh pendidikan misal al-Qabisi, Ibnu Sina dan juga alp-Ghazali, yang menyebutkan bahwa sebagian dari mereka ada yang menanamkan dengan pendidikan moral dan akhlak atau menganjurkan rasa keagamaan atau menetapkan kaidah yang tertentu (Al-Abrasyi, tt: 30 ).

Dari pernyataan di atas dapat ditarik kesimpulan bahwa tujuan pendidikan anak menurut Ibnu Khaldūn adalah penanaman akidah / keimanan dan akhlak yang mulia pada diri anak. Hal ini berarti bahwa anak lebih ditekankan pada tujuan ilmu agama, kemampuan agama dan akhlak yang baik dalam memberikan pengaruh yang besar untuk perkembangan anak sampai usia dewasa. Hal ini tersirat dalam pernyataan Ibnu Khaldūn dalam kitabnya Muqaddimah di atas tadi. Pendidikan agama dan pendidikan akhlak (budi pekerti) tidak ditumbuhkan kecuali sejak kecil atau usia dini, khususnya melalui kehidupan keagamaan yang saleh dan utama yang dihayati oleh keluarga itu yang dilakukan oleh anak di rumah, sekolah dan dalam masyarakat (Sulaiman, 1991: 73).

Jadi apabila dianalisa secara mendalam bahwa tujuan pendidikan anak menurut konsep Ibnu Khaldūn adalah membentuk anak agar menjadi orang dewasa yang berkepribadian baik, berbudi luhur, berakhlak mulia melalui nilai pendidikan dalam Alquran. Konsep Ibnu Khaldūn sesuai dengan konsep pendidikan Ibnu Sina yang menyatakan bahwa pendidikan akhlak (budi pekerti) ini merupakan tujuan utama dari pendidikan pada umumnya, sebab tujuan pendidikan itu adalah membentuk orang yang berakhlak mulia disamping membentuk kepribadian yang kuat di kalangan anak-anak. 
Membentuk kepribadian baik dan anak yang mempunyai akhlak mulia itu merupakan tujuan pokok, utama dan inti dari tujuan pendidikan anak menurut konsep Ibnu Khaldūn. Namun ketika anak sudah menginjak remaja dan dewasa maka tujuan pendidikan anak harus ditambah dengan tujuan hidup anak yaitu dia harus mempunyai alat atau keahlian yang dipelajari dari berbagai ilmu pengetahuan untuk dia di masa mendatang dalam arti untuk giat beraktivitas dan bekerja dalam mencukupi kehidupannya dan keluarganya.

Maka dapatlah dianalisa dengan menyimpulkan bahwa tujuan menurut konsep Ibnu Khaldūn ketika anak menginjak dewasa yaitu memberikan kesempatan kepada pikiran untuk aktif dan bekerja, karena aktifitas ini sangat penting bagi terbuka pikiran dan kematangan anak kemudian kematangan ini dapat memberikan manfaat pada masyarakat, memperoleh berbagai ilmu pengetahuan sebagai alat untuk membantunya hidup dengan baik di dalam masyarakat maju dan berbudaya, dan memperoleh lapangan pekerjaan yang digunakan untuk memperoleh rizki.

\section{Relevansi Tujuan Pendidikan Anak dengan Pendidikan dewasa ini}

Berbicara masalah pendidikan merupakan suatu kajian yang cukup menarik, karena pemahaman makna tentang pendidikan sendiripun juga beragam. Perlu diketahui bahwa banyak sekali istilah-istilah dalam pendidikan itu sendiri, seperti pengajaran, pembelajaran, paedagogi, pendidikan pelatihan, dan lain sebagainya. Semua itu dapat kita jumpai dalam buku-buku yang mengkaji tentang pendidikan.

Pendidikan menurut Marimba adalah bimbingan atau pimpinan secara sadar oleh pendidik terhadap perkembangan jasmani dan rohani anak didik menuju terbentuknya kepribadian yang utama (Marimba, 1989: 19). Dalam pendidikan yang dijelaskan tersebut di atas, bahwa dalam pendidikan terdapat beberapa unsur: 1) Usaha (kegiatan) yang bersifat bimbingan dilakukan secara sadar.2) Ada pendidik, pemimpin atau penolong, 3). Ada peserta didik, anak didik, 4).Bimbingan itu mempunyai dasar dan tujuan 5) Dalam usaha itu terdapat alat-alat yang pergunakan. 
Dari pemaknaan tersebut, dinyatakan bahwa pendidikan terbatas kepada pengembangan anak didik oleh pendidik. Jadi terdapat pengaruh dari orang per orang atau manusia lain secara sadar. Melihat kondisi pendidikan dewasa ini sebagaimana telah didiskripsikan, maka peniruan terhadap konsepsi pendidikan barat harus dihentikan, karena tidak sesuai dengan cita-cita Islam. Sebaliknya merupakan keniscayaan untuk mencari paradigma pendidikan yang paling sesuai dengan cita-cita Islam.

Dalam konteks ini, menjadi tanggung jawab moral bagi pakar muslim untuk membangun teori Islam sebagai paradigma ilmu pendidikan. Paradigma ilmu pendidikan yaitu penggunaan nilainilai Islam sebagai sudut pandang secara menyeluruh mengenai persoalan-persoalan yang berkaitan dengan gejala-gejala pendidikan dalam rangka menyusun teori pendidikan.

Dalam wacana ilmiah, setidaknya dapat dikemukakan beberapa alasan mendasar tentang pentingnya realisasi paradigma tersebut, pertama Islam sebagai wahyu Allah yang merupakan pedoman hidup manusia untuk mencapai kesejahteraan hidup di dunia dan akherat, baru bisa dipahami, diyakini, dihayati dan diamalkan setelah melalui pendidikan. Disamping itu secara fungsional, Nabi Muhammad Saw. sendiri diutus Allah sebagai pendidik umat manusia. Oleh karenanya bukan sesuatu yang mengada-ada bila Islam diangkat sebagai paradigma ilmu pendidikan. Kedua, ilmu pendidikan sebagi ilmu humaniora juga termasuk ilmu normatif, sebab ia terikat dengan norma-norma tertentu. Dini nilai-nilai Islam sangat memadai untuk dijadikan sentral norma dalam ilmu pendidikan. Ketiga, dalam menganalisa dan memecahkan berbagai permasalahan pendidikan, para ahli pendidikan ini cenderung mengambil sikap seakan-akan semua permasalahan pendidikan, baik mikro maupun makro diyakini dapat diterangkan dengan teori-teoriatau filsafat pendidikan barat, padahal yang disebut terakhir tadi bersifat sekuler. Oleh karena itu nilai-nilai ideal Islam mestinya akan lebih sesuai untuk menganalisa secara kritis fenomena kependidikan.

Paradigma yang ditawarkan olel Muhajir sangat teoritik dan filosofik. Karenanya telaah ulang lebih cermat diperlukan untuk ditampilkan pada taraf telaah substansial ilmu pendidikan, baik yang teoritk maupun yang terapan dan teknologik. 
Bahwa konsepsi pendidikan barat dewasa ini merupakan manifestasi dari persepsi peradaban barat terhadap realitas dunia. Maka meniru dan mengikuti mereka berarti menjadikan kaum muslimin budak bagi peradaban barat dan pandangan dunianya. Maka pendidikan Islam harus mampu mengantisipasi kebutuhan dan tantangan umat Islam di masa datang. Dalam konteks konseptualkeilmuan, harus bisa mengembangkan dan menemukan konstruk paradigma pendidikan yang berangkat dari pandangan dunia Islam.

Mengkaji tentang tujuan pendidikan Islam tidak dapat dilepaskan dari upaya memahami konsep dasar pendidikan Islam yang secara hakiki digali dan dikembangkan dari Alquran dan asSunnah, di samping merujuk kepada ijtihad para ahli. Keduanya merupakan tiang penyangga yang memelihara esensi dan tujuantuan fundamentalnya, baik yang harus dilestarikan maupun yang menghendaki kreasi terus menerus. Pendidikan dalam hal ini ditujukan untuk mempersiapkan manusia yang baik dan benar, yang mengabdi kepada Allah dalam pengertian yang sesungguhnya, serta memiliki kemauan dan kemampuan dalam membangun struktur kehidupan duniawinya sesuai dengan syariat dan melaksanakannya untuk menopang keimanannya. Kedua tujuan ini selaras dengan tujuan penciptaan manusia yang berfungsi sebagai hamba Allah dan berperan sebagai khalifah-Nya.

Pendidikan merupakan usaha dan kegiatan yang sarat dengan tujuan. Kedudukan tujuann dalam pendidikan cukup strategis, karena selain memberikan panduan tentang karakteristik manusia yang ingin dihasilkan oleh pendidikan tersebut, sekaligus pula menentukan arah dan langkah-langkah dalam melakukan seluruh kegiatan dan proses penyelenggaraan pendidikan. Oleh karena itulah berbagai pembahasan dan penelusuran terhadap suatu sistem pendidikan seringkali mengalami ketidakberhasilan disebabkan mengabaikan kajian terhadap konsep-konsep tujuan pendidikan yang dicanangkannya. Hal itu berarti bahwa untuk memahami konsep-konsep pendidikan Islam, tentulah diperlukan pemahaman yang memadai tentang tujuan pendidikan Islam sebagaimana disajikan pada uraian-uraian berikut.

Telah dikatakan di depan bahwa pendidikan merupakan suatu usaha dan kegiatan yang sarat dengan tujuan. Kedudukan 
tujuan dalam pendidikan cukup menentukan, karena selain memberikan panduan tentang karakteristik manusia yang ingin dihasilkan pendidikan, sekaligus pula memberikan arag dan langkah dalam melakukan seluruh kegiatan pendidikan.

Dalam hubungan ini, Muhammad Qutb, guru besar pengkajian Islam pada Universitas King Abdul Aziz Mekah ketika mengawali tulisannya dalam buku Minhaj al-Tarbiyah al-Islamiyyah segera mempertanyakan, "Apakah yang paling ditekankan dalam sistem pendidikan Islam, saranakah atau tujuan?” (Qutb, 1983: 11). Meskipun Qutb tidak memberikan jawaban tuntas atas pertanyaan yang diajukannya itu tetapi jelas terlihat bahwa dia memandang tujuan pendidikan merupakan unsur strategis yang lebih penting dari pada sarana, karena sarana itu akan selalu mengalami perubahan dari masa ke masa dari generasi ke generasi.

Demikian pentingnya kedudukan tujuan dalam pendidikan Islam menyebabkan banyak pakar yang menolak pendidiknan tanpa tujuan akhir yang jelas. Atas dasar itulah pendidikan Islam menolak sikap yang dikembangkan John Dewey (1859-1952) seorang filosof pendidikan Amerika yang keberatan menerima adanya suatu tujuan final dalam pendidikann. Dalam hal ini Dewey menganggap bahwa orang-orang yang membuat tujuan final bagi pendidikan telah meletakkan "sesuatu" yang lain di luar aktivitas pendidikan dan bukan berada di dalamnya (Dewey, 1980: 121).

Akan halnya Omar Muhammad al-Toumy al-Syaibani, guru besar Falsafah Pendidikan Islam pada Universitas Tripoli Libya, meskipun tidak keberatan terhadap "pertumbuhan sebagai bagian dari tujuan pendidikan, tetapi makna pertumbuhan yang dimaksudkan itu sebaiknya diarahkan kepada pertumbuhan yang dikehendaki dan bukan pertumbuhan yang bebas tak terkendali, melainkan dengan memberi isi dan makna pada pertumbuhan itu akan nilai-nilai yang bermuatan spiritual dan akhlak di dalam seluruh proses dan aktivitas pendidikan yang dilaksanakan (asSyaibani, 1979: 410).

Kritik-kritik yang dikemukakan para ahli pendidikan Islam terhadap Dewey itu menunjukkan urgensi tujuan pendidikan. Jenis tujuan apapun yang hendak digunakan pendidikan Islam baik 
tujuan perantara maupun sementara, maupun tujuan-tujuan khusus tidak boleh lepas dari inti tujuan idealnya yang senantiasa inheren dengan iman dan amal saleh sebagai nilai-nilai badi yang menjadi tujuann fundamental dalam pendidikan Islam. Sebagai contoh, bahwa Islam jelas-jelas keberatan menerima tujuan pendidikan yang dikemukakan oleh kalangan Humanistic Mental Discipline yang hanya bertumpu untuk mewujudkan manusia intelek dan cerdas. Konsep ini berakar dari pemikiran klasik Plato dan Aristotels dan dikembangkan lagi oleh para Humanis abad ke 20 seperti Robert M. Hutchins dan Mortimer J.Adler (Bigge, 1994: 29). Mereka lebih mengagungkan manusia sebagai makhluk yang terdiri atas mind dan organisme biologis yang sama- sama memiliki otot-otot yang khas. Mind sebagai substansi non fisik mempunyai kekuatan ntuk mengingat, ada keinginan, ketetapan hati dan lain sebagainya yahg apabila dilatih secukupnya akan dapat beroperasi dengan sendirinya (Bigge, 1994: 24) Dengan demikian maka tujuan terttinggi suatu pendidikan adalah mengolah Mind atau intelek agar mencapai taraf yang tinggi.

Senada dengan itu, John Locke juga mengemukakan tujuan pendidikan untuk membentuk manusia gentlman yang mengutamakan kepribadian berdasarkan pengetahuan. Karena itu seprti dikatakan Sutan Zanti Arbi bahwa tujuan pendidikan John Locke hanya semata-mata untuk mengembangakn kemampuan bernalar (Arbi, 1988: 97). Memang Locke berusaha mengharmoniskan pendidikan rohani dan jasmani, tetapi pendidikan rohani yang dimaksudkannya bukan bersumber dari ajaran agama yang diwahyukan Tuhan, melainkan berasal dari hasil pemikiran manusia. Locke tidak mengakui Tuhan berdasarkan pemberitaan wahyu, tetapi Tuhan wajib dipercayai dengan jalan rasio atau akal. Karena itu Locke tidak bisa menerima ajaran moral yang bersumber dari ktab suci. Ia hanya mengajarkan moral berdasarkan kemanfaatan praktisnya (Sujono, 1978: 19).

Seperti juga Locke, J.J. Rousseau juga menekankan tujuan pendidikan untuk membentuk manusia bebas dan merdeka dari tekanan manapun maupun ikatan serta tidak untuk tujuan tertentu, apakah itu menjadikan peserta didik menjadi seorang beragama atau menjadikan warga masyarakat dan warga negara yang baik, juga 
tidak untuk suatu jabatan melainkan semata-mata menjadi seorang individu yang bebas. Rousseau dalam hal ini hanya percaya pada alam. Alamlah yang berhak memberikan pendidikan kepada peserta didik secara bebas dan alamiah. Karena itu ia membuat gagasan agar peserta didik dijauhkan dari masyarakat karena hal itu dapat merusak kepribadian peserta didik yang telah diciptakan Tuhan dalam keadaan baik sejak pertama kalinya. Menurut pendapatnya, peserta didik pada dasarnya baik; dan masyarakat itulah yang kurang baik. Kebaikan alamiah manusia itu menurut Rousseau hanya dapat dipelihara oleh pendidikan dari alam, dan bukan dari masyarakat (Siddik, 2005: 19-30).

Rousseau percaya bahwa setiap manusia mempunyai tiga guru, yaitu "alam", "orang-orang" dan hal-hal atau bendabenda. Alam mengembangkan daya-daya dan organ-organ yang terdapat dalam diri manusia. Sedangkan pengembangan maknanya merupakan pendidikan yang diberikan manusia. Kepandaian dalam memahami obyek-obyek merupakan pengaruh didikan bendabenda. Apabila ketiga guru tersebut menghasilkan tujuan yang sama maka manusia akan mencapai tujuan yang benar.

Apakah sebenarnya tujuan pendidikan yang benar itu? Jawabannya adalah nature (alam). Rousseau mendefinisikan nature sebagai sifat bawaan dan bakat-bakat asli yang belum dimodifikasi oleh pengaruh kebiasaan-kebiasaan yang lain (Siddiq, 2005: 156).

Oleh karena pendidikan dari orang-orang dapat mengubah sifat bawaan asli manusia, maka haraan Rousseau lebih bertumpu pada dua guru lainnya, alam dan benda-benda dengan tetap menjaga agar pendidikan dari orang-orang berada pada profil terendah. Karena itu Rousseau menawarkan suatu pendidikan seperti yang diperbuatnya kepada Emile, yang dijauhkan dari lingkungan orang-orang dengan memindahkannya ke daerah pedalaman dengan bantuan tutor yang terlatih. Dengan cara seprti itu peserta didik, menurut pendapatnya, terbebas dari kompleksitas dan kotradiksikontradiksi masyarakat yang dapat menariknya pada suatu keadaan dan keinginan yang tak sesuai dengan bawaan alamiahnya.

Memang, dasar berpijak Rousseau dalam membangun konsep pendidikannya kelihatannya mempunyai nilai positif agar 
sifat dasar alamiah manusia yang datang dari Tuhan itu tidak sampai rusak di tangan orang-orang. Tetapi karena Rousseau menjauhkan peserta didik dari masyarakat maka nilai yang positif tadi telah kehilangan maknanya.

Rousseau berbuat seperti itu agar sifat alamiah peserta didiknya dapat berkembang secara alamiah yang dapat mewujudkannya menjadi "orang" dan bukan menjadi seorang pengacara atau menjadi tentara dan polisi, bahkan tidak akan menjadi seorang pendeta, tetapi yang paling utama seperti yang terlihat dalam pernyataannya di atas, peserta didiknay akan menjadi manusia.

Rousseau tidak ingin peserta didiknya menjadi "orang lain”, tetapi tetap menjadi dirinya sebagai individu yang bebas dalam menentukan masa depannya sendiri. Untuk memenuhi obsesinya itu, tampaknya Rousseau telah mengorbankan nilai pendidikan sosial yang memungkinkan peserta didiknya kehilangan rasa sosialnya karena dijauhkan dari kehidupan bermasyarakat. Dengan demikian tujuan pendidikan Rousseau hanyalah untuk menciptakan individu yang bebas dan alamiah, termasuk menjadi penganut agama alamiah ( natural religion). Sebagai seorang penganut agama alamiah, Rousseau tidak percaya terhadap ajaran yang diwahyukan. Dia hanya bertuhan melalui pengalamannya saja. Meskipun begitu Rousseau tidak setuju terhadap ateisme, karena menurut pendapatnya seorang ateis bukanlah seorang yang jujur sekurang-kuranya terhadap dirinya sendiri (Siddiq, 2005: 156).

Jadi kalau dianalisis bahwa tujuan pendidikan anak menurut Ibnu Khaldūn itu masih relevan dengan pendidikan dewasa ini yang dipelopori oleh aliran pembaharuan pendidikan yang ditokohi oleh Fouerster, seorang ahli pendidik dari Jerman dengan sekolah kerjanya. Ibnu Khaldūn mengatakan bahwa penanaman akhlak dan moral yang baik pada anak itu dimulai sejak usia dini dengan mempelajari Alquran dan syi'ir-syi'ir yang bernilaikan dan berisikan cerita-cerita atau kisah para tokoh dan pahlawan, agar pelajaran itu membekas pada kejiwaan anak dan untuk menjadikan kepribadian yang baik dan nantinya setelah dewasa menjadi manusia yang baik dan berbudi luhur dan hal ini adalah pendidikan iman dan akhlak yang ditanamkan Ibnu Khladun pada anak. Ibnu Khaldūn juga tidak 
menerangkannya secara panjang lebar, namun yang terpenting dalam mendidik anak tujuan utama dan pertama adalah pendidikan akhlak dan keimanan, kemudahan dilanjutkan dengan tujuan akal atau intelektual. Baru setelah itu anak dapat dibimbing dan diarahkan dengan pendidikan kecerdasan, keaktifan, kreatifitas sehingga anak dapat tumbuh dengan baik dan sesuai dengan perkembangan anak. Saya kira konsep Ibnu Khaldūn mengenai pendidikan anak masih dan sangat relevan dengan konsep pendidikan anak dewasa ini.

Selanjutnya dalam mengajarkan Alquran maka tujuan yang dharapkan adalah agar anak mampu membaca dan menceritakan Alquran, juga anak nantinya akan menghafal dan memahami makna beberapa kutipan terpilih atau surat yang penting. Begitu juga dalam mengajarkan Hadis, diharapkan anak-anak-anak akan belajar mengenai kehidupan dari Rasulullah nabi Muhammad saw dan para sahabatnya serta nabi-nabi lainnya (Ashraf, 1993: 128-129).

Dalam mengajarkan syi'ir yang di dalamnya mengandung cerita, kisah yang menarik dari para tokok kaum muslim, diharapkan anak mempunyai rasa perhatian dan simpati kepada teman-teman mereka, ketaatan kepada orang tua atau yang lebih dewasa. Juga dalam pengajaran bahasa Arab anak diberikan penguasaan kata-kata dasar dan struktur bahasa Arab, sehingga dalam pelajaran bahasa Arab selajutnya tidak mengalami kesulitan (Ashraf, 1993: 118). Anak-anak diharapkan juga mempelajari makna atau arti dari nilai-nilai Islam melalui isi, bahasa dan contoh dari matematika dasar, yang nantinya digunakan dan dipraktekkan dalam kehidupan mereka (Ashraf, 1993: 129). Disinilah letak keagungan konsep Ibnu Khaldūn tentang pendidikan Islam yang mengkhususkan pada pendidikan anak, yang sebagian besar konsep-konsep pendidikan beliau masih relevan dengan konsep pendidikan anak dewasa ini. Begitu juga tentang materi dan metode pendidikan anak banyak yang relevan dengan pendidikan anak dewasa ini, apalagi Ibnu Khaldūn adalah seorang tokoh pendidikan yang sedikit berbeda dengan tokoh pendidikan Islam sebelumnya. 
Noor Hidayah

\section{Simpulan}

Dari uraian di atas dapat diambil kesimpulan sebagai berikut:

1. Konsep pendidikan anak menurut Ibnu Khaldūn dalam kitab Muqaddimah didasarkan pada Alquran, sehingga pendidikan yang digagas dan dicetuskan oleh Ibnu Khaldūn berpijak pada ketentuan Alquran baru kemudian di landasi dengan ketentuan intelektual dan akal.

2. Tujuan pendidikan anak menurut pemikiran Ibnu Khaldūn dalam kitab Muqaddimah adalah membentuk anak supaya memiliki akhlak yang mulia, kepribadian yang baik dan tangguh, memiliki malakah atau ketrampilan dan menguasai ilmu-ilmu agama (naqliyah) dan ilmu-ilmu umum (aqliyah) untuk eksistensi kelangsugan hidup mereka.

3. Konsep pendidikan anak menurut Ibnu Khaldūn dalam kitab Muqaddimah ternyata masih relevan dengan tokoh-tokoh pendidikan Barat, misalnya Locke, J.J. Rousseau Locke, Fouerster, dan John Dewey, namun pijakan dalam berpikir mereka berbeda dengan Ibnu Khaldūn, mereka lebih menekankan dan didominasi oleh pijakan akal dan rasional. 


\section{DAFTAR PUSTAKA}

Ahmad Syafi'i Ma'arif, Ahmad Syafi'i. 1996. Ibnu Khaldūn dalam Pandangan Penulis Barat dan Timur. Jakarta: Gema Insani Press.

Ahmad, Zaenal Abidin. 1979. Ilmu Politik Sejarah Islam dan Umatnya Sampai Sekarang (Perkembangan dari Zaman ke Zaman). Jakarta: Bulan Bintang.

al-Abrasyi, Athiyah. tt. Ruh at-Tarbiyah wa Ta'lim. Dar-al-Ihya': Bab al-Halabi.

. tt. al-Tarbiyah al-Islamiyah wa Falasifatuha. Beirut: Dar alFikr.

Ali, A. Mukti. 1970. Ibnu Khaldūn dan Asal-Usul Sosiologi. Yogyakarta: Yayasan Nida.

al-Jumbulati, Ali. 1994. Perbandingan Pendidikan Islam. terj. H.M. Arifin, Jakarta: Rineka Cipta.

al-Syaibani, Omar Muhammad al-Toumy. 1979. Falsafah Pendidikan Islam. terj. Hasan Langgulung, Jakarta: Bulan Bintang.

an-Nahlawi, Abdurrahman. 1992. Prinsip-prinsip dan Metode Pendidikan Islam dalam Keluarga, di Sekolah dan di Masyarakat. Bandung: Diponegoro.

Arifin, M. 1979. Hubungan Timbal Balik Pendidikan Agama di Lingkungan Sekolah dan Keluarga. Jakarta: Bulan Bintang.

Ashraf, Ali. 1993. Horison Baru Pendidikan Islam. terj. Sori Siregar, Jakarta: Pustaka Firdaus.

Barnadib, Imam. dan Barnadib, Sutari Imam. 1996. Beberapa Aspek Substansial Ilmu Pendidikan, Yogyakarta: Andi Offset.

Bisri, Cik Hasan. 1998. Penuntun Penyusunan Rencana Penelitian dan Penulisan Skripsi: Bidang Ilmu Agama Islam. Ciputat: Logos Wacana Ilmu.

Bisri, Cik Hasan. dan Rufaidah, Eva. 2002. Model Penelitian Agama dan Dinamika Sosial. Jakarta: Raja Grafindo Persada.

Dewey, John. 1980. Democracy and Education. New York: Tehe Macmillan Company. 
Noor Hidayah

Djamarah, Syaiful Bahri. dan Zain, Aswan. 2002. Strategi Belajar Mengajar Jakarta: Rineka Cipta.

Enam, M.A. 1979. Ibn Khaldūn His Life and Work, New Delhi: New Taj Offser Press.

Fahmi, Asma Hasan. 1979. Sejarah dan Filsafat Pendidikan Islam. terj. Ibrahim Husein, Jakarta: Bulan Bintang.

Fikri, Ali. tt. Tarbiyatul Banin. Beirut: Dar al-Kutub Ilmiah.

Kartono, Kartono. 1995. Psikologi Anak (Psikologi Perkembangan). Bandung, Mandar Maju, Cet. I.

Khaldūn, Ibnu. tt. Muqaddimah Ibnu Khaldūn. Mesir: Dar al-Fikr.

Lenoil, M. 2001. Educational Ideologies Comtemporary of Educational Philosophies. alih bahasa: Intan Naumi .Yogyakarta: Pustaka Pelajar.

Lewis, B. et. al., 1971. The Encyclopedia of Islam. Tuta Subagide Pallos EJB, London: Inzac.

Ma'arif, Ahmad Syafi'i. 1996. Ibnu Khaldūn dalam Pandangan penulis Barat dan Timur. Jakarta: Gema Insani Press.

Marimba, Ahmad D. 1989. Pengantar Filsafat Pendidikan Islam. Bandung: al-Ma'arif.

Moleong, Lexy J. 1993. Metodologi Penelitian Kualitatif. Bandung: Remaja Rosda Karya.

Morris L. Bigge, Morris L. 1994. Learning Theories for Teacher. New York: Harper dan Row Publishers Inc.

Muhadjir, Noeng. 1989. Metodologi Penelitian Kualitatif. Yogyakarta: Rake Sarasin.

Mulkhan, Abdul Munir. 1993. Paradigma Intelektual Muslim Pengantar Filsafat Pendidikan Islam dan Dakwah. Yogyakarta: Sipress.

Muslim, tt. Shahih Muslim Juz II, Beirut: Dar al-Fikr.

Nasution, S. 1986. Didaktik Asas-Asas Mengajar. Bandung: Jemmars.

Poerwadarminta, W.J.S. 1999. Kamus Umum Bahasa Indonesia. Jakarta: Balai Pustaka.

Qutb, Muhammad. 1983. Minhaj al-Tarbiyah al-Islamiyyah. Beirut: Dar- al-Syuruq, Cet. VII. 
Raliby, Osman. 1965. Ibnu Khaldūn Tentang Masyarakat dan Negara. Jakarta: Bulan Bintang.

Smith, Samuel. 1986. Gagasan-gagasan Besar Tokoh dalam Bidang Pendidikan. Jakarta: Bumi Aksara.

Soejoed, 1977. Aliran-aliran Pendidikan dan Pengajaran dengan Tokohtokohnya, Yogyakarta: IKIP.

Soejono, Agus. 1978. Aliran Baru Dalam Pendidikan. Bandung: CV. Ilmu.

Sulaiman, Fathiyah Hasan. 1991. Ibnu Khaldūn Tentang Pendidikan. terj. Azra'i Zakariya, Jakarta: Minaret. . 1964. Bahs al-Madzhab al-Tarbawi "Inda al-Ghazali. Mesir: Maktab Nahdah.

Suparlan, Y.B. 1984. Aliran-aliran Baru dalam Pendidikan. Yogyakarta: Andi Offset.

Surachmad, Winarno. 1972. Dasar dan Teknik Reseacrh, Bandung: Tarsito.

Syah, Muhibbin. 2001. Psikologi Belajar. Jakarta: Logos.

Thoha, Nashruddin. tt. Tokoh-tokoh Pendidikan Islan dizaman Jaya Iman Ghazali dan Ibnu Khaldūn. Jakarta: Mutiara.

Ulwan, Abdullah Nasih. 1992. Pendidikan Anak menurut Islam kaidahkaidah. Bandung: Remaja Rosdakarya.

Wafi, Ali Abd al-Wahid. 1985. Ibnu Khaldūn Riwayat dan Karyanya. Jakarta: Grafiti Press. . 1985. Ibnu Khaldūn Riwayat dan Karyanya. Jakarta: Grafiti Press. 
halaman ini bukan sengaja dikosongkan 